\title{
A STUDY OF CAR DEMAND AND ITS INTERDEPENDENCY IN SARAWAK
}

\author{
Nur Zaimah Ubaidillah* \\ Universiti Malaysia Sarawak
}

\begin{abstract}
Several developing Asian countries recorded a high level of private based motorisation, specifically car and motorcycle ownership. Continuous rise in the level of private motorisations may lead to issues such as traffic congestions, high fuel consumption and pollutions. For that reason, there is a need to investigate the determinant of car ownership and the interdependency between car and motorcycle ownership in Sarawak, Malaysia. This study used time series annual data using vector error correction model (VECM) from 1980 to 2018. Based on the analysis, it is found that gross domestic product, fuel price and population density are significant determinants of car ownership. The findings revealed that as the standard of living rises, car demand increases. At the state aggregate level, it is found that there is a substitution relationship between both modes. This indicates that people are highly likely to shift from motorcycle ownership to car ownership in the long run. Based on the findings, the policy recommendations in the study include encouraging shifts to alternative modes of transport through public transport reforms as well as improving facilities for a more sustainable mode of transportation in Sarawak.
\end{abstract}

Keywords: Car ownership; motorcycle ownership; interdependency; vector error correction model; fuel price; gross domestic product, SDG7

Received: 27 April 2020

Accepted: 14 September 2020

\section{INTRODUCTION}

Since the discovery of the vehicle in the 19th century, the role of cars has become considerably vital all over the world. Originally, the needs of possessing cars were primarily due to economic expansion, which leads to shifts in trends in employment, societal surroundings, and infrastructure advancement. Moreover, the capacity to gain access to rural areas and the convenience achieved via mobility allowed individuals to participate in economic endeavours. The necessity to travel in the period of the industrial revolution fundamentally led to the development of the car manufacturing sector, generating jobs and also government income via taxation. Internationally, there was a significant growth in the number of registered cars, rising by 45 per cent between 2005 and 2015 (OICA, 2018). Nevertheless, over the past few years, the increase in population, urbanisation and the economy has altered the patterns in travelling in various territories of the world, which brings our interest to Asian developing nations. This is specifically crucial as the Asian region is predicted to have 60 per cent of the world's population by 2050 . Provided the

\footnotetext{
* Corresponding author: Faculty of Economics and Business, Universiti Malaysia Sarawak, 94300 Kota Samarahan, Sarawak; Phone: +6082-584421; Email: unzaimah@unimas.my
} 
population spur, there is a high probability that there will be sizable growth in motorisation in this region. In fact, Asian developing countries have undergone rapid progress in motorisation. Between 1999 and 2016, the number of vehicles per 1000 population for Far East Asian countries increased significantly, by 170 per cent (105.6 vehicles per 1000 population in 2016), in comparison with the 5 per cent (606 vehicles per 1000 population in 2016) and 14 per cent (831.9 vehicles per 1000 population in 2016) rises in Western European countries and the USA, respectively, at the similar period of time (Davis \& Boundy, 2019).

While cars are commonly deemed as the key measure for motorisation, it shows to be otherwise for Asian developing countries. This is because the Asian region has a high level of motorcycle ownership in comparison with the rest of the world (Senbil, Zhang, \& Fujiwara, 2007). The increase of motorcycle ownership and use is at a very high level, mainly in low- and mediumincome countries. Barter (1999) presented the term motorcycle cities to explain cities which are motorcycle-oriented, including Ho Chi Minh (Vietnam), Phnom Penh (Cambodia) and Vientiane (Laos). The key rationale for such high motorcycle ownership and use in Asian developing countries is because of the affordability of motorcycles and insufficient access to public transport. In Asian developing countries, there is a very distinct range in terms of motorisation compared to developed countries. Some Asian developing countries inclined to have very high car ownership and low motorcycle ownership, and vice versa. However, other Asian developing countries show a high level of motorisation in terms of both car and motorcycle ownership. In a study by Senbil et al., (2007), there are 65.9 motorcycles per 1000 population in wealthy Asian cities and a staggering 117.21 motorcycles per 1000 population in other Asian cities. Both regions of Asian cities have the highest level of motorcycle ownership in comparison with other regions in the world. It shows that some other cities in Asia are after similar high motorcycle ownership patterns, including Malaysia (Kuala Lumpur), Indonesia (Jakarta), Thailand (Bangkok) and Vietnam (Hanoi) with levels of motorcycle ownership larger than 100 motorcycles per 1000 inhabitant (Hsu et al., 2003; Sanko et al., 2014).

Transport is associated with energy hence related to the UN Sustainable Development Goal 7 which is to "Ensure access to affordable, reliable, sustainable and modern energy for all" (United Nation, 2015). The rise in motorisation trajectory in the developing countries specifically car ownership leads to issues such as traffic congestions, high fuel consumption and transport-based emissions. It is expected that by the year 2030, there may be a significant increase in private vehicle fleet along with the GDP increment (United Nation, 2015). Furthermore, the share of global total final energy consumption is 28.8 per cent and consumed approximately 65 per cent of global oil supply in 2015 (United Nation, 2018). While developing Asian countries have similar trend of high car and motorcycle ownership, it is however uncertain if such relationship persists in the long-run. It is also likely that people tend to shift from motorcycle to car ownership as they improve their standard of living. Hence, studies on the socio-economic and built-environment determinant of car ownership and also the interdependency of private motorisations in the case of developing Asian countries is essential. In this study, Sarawak, a state in Malaysia is selected as it has almost similar trajectory with other cities in the developing Asian country. 


\subsection{Car Ownership in Sarawak}

Private vehicle ownership in Malaysia, a developing country, is among the highest in the world. In a decade, Malaysia experience vast increment of 70 per cent in total registered cars and 55 per cent of total registered motorcycle from 2008 to 2017, higher than the population increment of 16 per cent (CEIC, 2019) . Malaysia ranked as the 7th highest registered motorcycles in the world (8.4 million) behind other Asian developing countries such as Indonesia, Thailand, and Taiwan. The country ranked behind Indonesia as the 18th highest registered cars in the world. However, Malaysia ranked 36th in 2011 with 334 cars per 1000 inhabitants while Brunei ranked as 5th in the world with 696 cars per 1000 inhabitants. The statistics show that Malaysia has a very high level of private motorisation for both car and motorcycle. Despite its statistical significance, very few works of literature are found on car and motorcycle ownership interdependency in Malaysia which suggest for further research in this study. In 2017, the Department of Statistics, Malaysia recorded Sarawak as the fourth highest GDP per capita (USD 12,403), behind Kuala Lumpur, Labuan and Penang states (DOSM, 2019). However, in terms of the overall GDP, Sarawak is the 3rd highest after Selangor and Kuala Lumpur. The economic significance of Sarawak in Malaysia shows that there is high economic activity and hence, sizeable demand for travel needs and mobility. For this reason, Sarawak, in particular, is selected as the case study site. Other than its economics contribution to Malaysia, the high level of car ownership explains Sarawak as the case study site for the study. Overall, all states in Malaysia are found to have a very high level of car ownership (Figure 1). The high level of private vehicle ownership is supported with Sarawak level of private motorisation, which experiences a substantial rise in many decades as depicted in Figure 2. There is an increment of 61 per cent of total registered cars, and 68 per cent of total registered motorcycle from the period of 2008 to 2017 (CEIC, 2019).

Figure 1: Percentage of Car Ownership in Malaysian Rural and Urban Areas (2014)

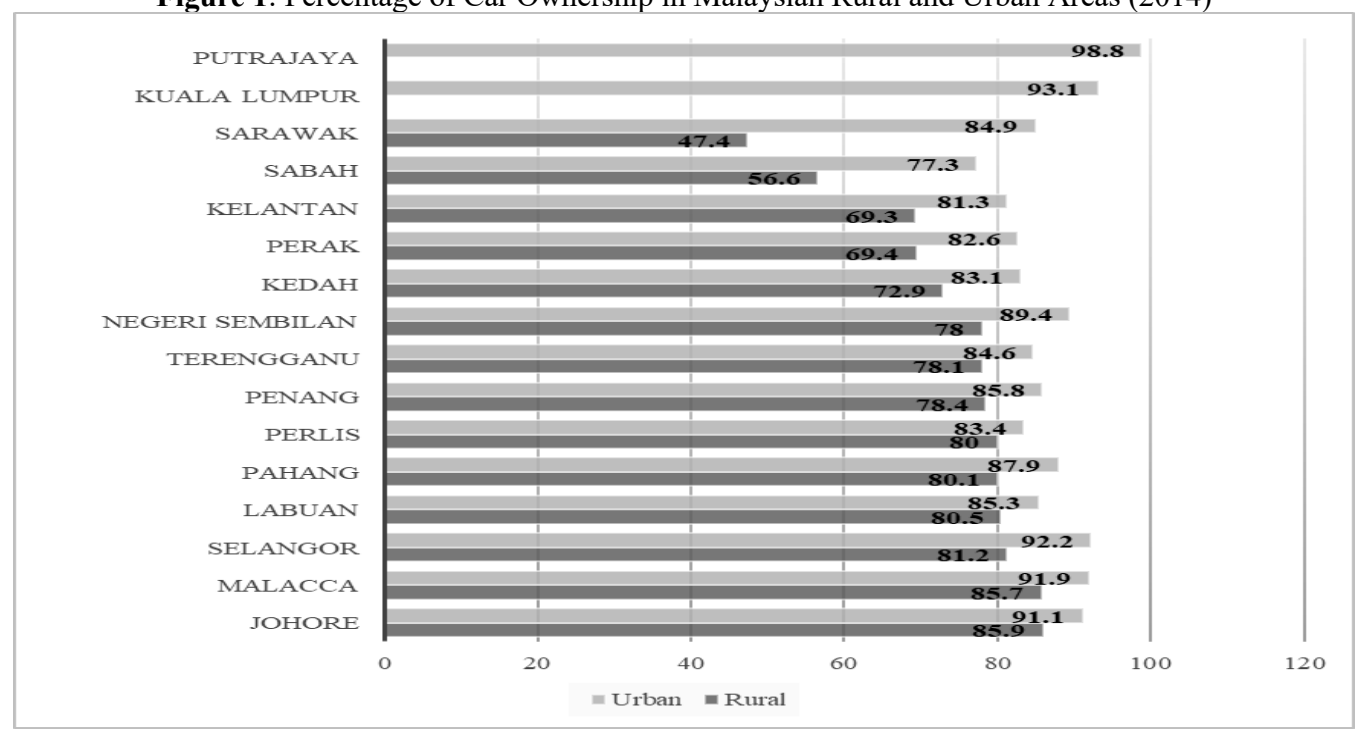

Source: Department of Statistics Malaysia (DOSM, 2016). 
Figure 2: Total registered vehicles in Sarawak (1980-2014)

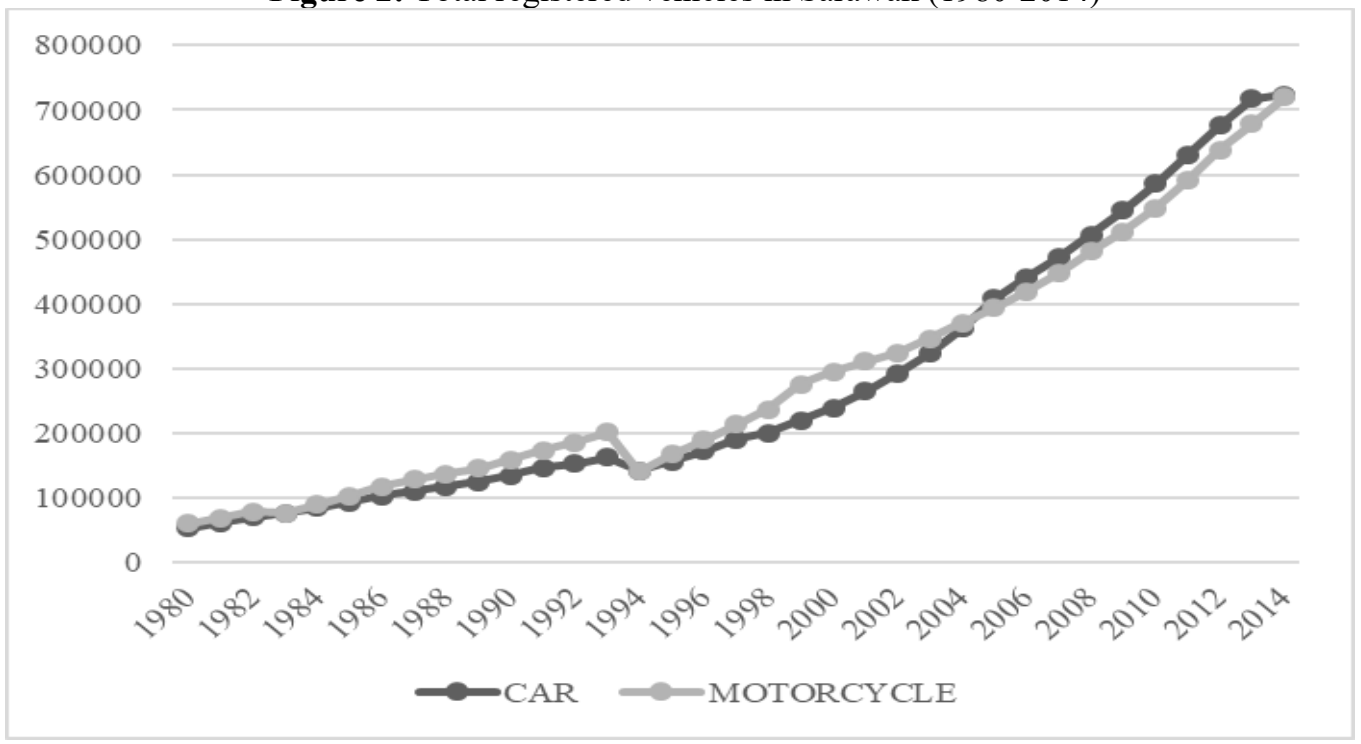

The increment is found to be slightly lower for cars but higher for a motorcycle during the same period in comparison with the Malaysian statistics. Presumably, both modes of transport are seen to have equal importance in the road users travel activities as Figure 2 indicates that there is no massive difference between the registered car and motorcycle. This raised questions as for whether car and motorcycle are complementary or substitutes in the case of Sarawak. The simultaneous rise of both car and motorcycle ownership in Sarawak initiates the necessity to assess the interdependency between these private modes of transport. One of the main rationales for high car and motorcycle dependence is the inadequate public transport infrastructure and services in most of these countries (Herwangi, 2018). Many studies on the interdependency of car and motorcycle ownership were clustered in developing Asian countries as these countries establish a high level of both modes compared to the developed countries (Yamamoto, 2009; Sanko et al., 2014). In a past study by Tuan (2011), it was discovered that there is a substitution relationship between car and motorcycle ownership at the aggregate level in Malaysia. A similar relationship was observed by Yamamoto (2009) in a research conducted in Kuala Lumpur at the disaggregate level. Moreover, Sanko et al., (2014) found that there are substitution relationships between car and motorcycle ownership in Bangkok, Thailand, and Kuala Lumpur, Malaysia, aside from a complementary relationship in Nagoya, Japan. This paper is organized into five sections entailing of the introduction, literature review, data and methodology, empirical results and summary and conclusion.

\section{LITERATURE REVIEW}

This section explains how private vehicles, namely cars and motorcycles, interdepend on each other. Economic development has enhanced the pace of motorisation in many developing countries. Nevertheless, contrasting their developed counterparts, the increase in motorisation, predominantly 
in Asian developing countries, is not only governed by cars but also by motorcycle ownership. Generally, motorcycle ownership is deemed as an inferior mode of transport in many countries as it cannot offer the convenience and freedom of cars. Nevertheless, such an outlook may be dissimilar for each country. Difficulties such as acute congestion and very deficient public transport may also add to high motorcycle ownership. Therefore, it is essential to assess the interdependency between car and motorcycle ownership, the study of which can be conducted using various methods/models (refer to Table 1).

Table 1: Studies on the Interdependency between Car and Motorcycle Ownership

\begin{tabular}{|c|c|c|c|}
\hline Aggregate & $\begin{array}{l}\text { Country/Case } \\
\text { Study }\end{array}$ & Model/Methodology & Interdependency \\
\hline $\begin{array}{l}\text { Pongthanaisawan and } \\
\text { Sorapipatana (2010) }\end{array}$ & Thailand & Logistic function & Substitution \\
\hline Tuan (2011) & $\begin{array}{l}\text { Japan, South } \\
\text { Korea, Taiwan, } \\
\text { Malaysia, } \\
\text { Indonesia }\end{array}$ & $\begin{array}{l}\text { Quadratic log-linear } \\
\text { models, logistic model }\end{array}$ & $\begin{array}{l}\text { Japan: Substitution } \\
\text { South Korea: } \\
\text { Substitution } \\
\text { Taiwan: Substitution } \\
\text { Malaysia: Substitution } \\
\text { Indonesia: Substitution }\end{array}$ \\
\hline Disaggregate & $\begin{array}{l}\text { Country/Case } \\
\text { Study }\end{array}$ & Model/Methodology & "Interdependency \\
\hline Yamamoto (2009) & $\begin{array}{l}\text { Osaka, Japan } \\
\text { Kuala Lumpur, } \\
\text { Malaysia }\end{array}$ & $\begin{array}{l}\text { Trivariate binary probit } \\
\text { model }\end{array}$ & $\begin{array}{l}\text { Osaka: Bicycle as } \\
\text { substitute for car } \\
\text { Kuala Lumpur: } \\
\text { Motorcycle as } \\
\text { substitute for car }\end{array}$ \\
\hline Sanko et al., (2014) & $\begin{array}{l}\text { Nagoya, Japan, } \\
\text { Kuala Lumpur, } \\
\text { Malaysia \& } \\
\text { Bangkok, } \\
\text { Thailand }\end{array}$ & $\begin{array}{l}\text { Bivariate ordered } \\
\text { probit model }\end{array}$ & $\begin{array}{l}\text { Nagoya: } \\
\text { Complementary } \\
\text { Kuala Lumpur: } \\
\text { Substitution } \\
\text { Bangkok: Substitution }\end{array}$ \\
\hline Hsu et al., (2007) & Taiwan & Poisson model & Substitution \\
\hline Chiou et al., (2009) & Taiwan & $\begin{array}{l}\text { Multinomial logit } \\
\text { model } \\
\text { Nested logit model }\end{array}$ & Substitution \\
\hline Senbil et al., (2007) & $\begin{array}{l}\text { Jabotabek, } \\
\text { Indonesia } \\
\text { Manila, } \\
\text { Philippines } \\
\text { Kuala Lumpur, } \\
\text { Malaysia }\end{array}$ & $\begin{array}{l}\text { Bivariate ordered } \\
\text { probit model }\end{array}$ & $\begin{array}{l}\text { Jabotabek: N/A } \\
\text { Manila:N/A } \\
\text { Kuala Lumpur: } \\
\text { Substitution }\end{array}$ \\
\hline
\end{tabular}

Few literatures were found to study vehicle ownership at the aggregate level in the developing countries. These studies mainly incorporated the macroeconomic indicators as the determinants of vehicle ownership, specifically car ownership or car sales (Samad Nawi et al., 2013; Islam, Ghani, Kusuma, \& Hong, 2016; Sandu, 2015). Generally, the macroeconomic indicators include gross domestic product (GDP), unemployment rate, interest rate and exchange rate. Studies by Samad Nawi et al., (2013) and Islam, Ghani, Kusuma, \& Hong (2016) using Malaysia as the country of study has idenfitied that these macroeconomic variables are significant in explaning car ownership. 
However, there is no study that has been made at the state level on the vehicle ownership in Malaysia. Furthermore, studies on the interdependency of private mode of transport (specifically car and motorcycle ownership) in general is still limited both at the aggregate and disaggregate level. At the aggregate level, studies on interdependency between car and motorcycle ownership were primarily conducted in the developing Asian countries (Pongthanaisawan \& Sorapipatana, 2010; Tuan, 2011).

Pongthanaisawan and Sorapipatana (2010) examined the relationship between motorcycles per 1000 people (MAO) with passenger cars per 1000 people (CAO) in Thailand using aggregate data from the period of 1991-2007. They found that as revenue increases, there is a shift to CAO for rationales such as stature, ease and safety. In a further aggregate-based study by Tuan (2011) on the dynamic interaction among motorcycle and car ownership in Asia, it was observed that households in developing countries opt for multiple motorcycles per household at low income and later opt for their first cars. Nevertheless, existing motorcycle ownership may impede the purchase of more cars. A more comprehension of the interdependency between both modes can be seen in past literatures utilizing disaggregated data. Yamamoto (2009) studied the interdependency between various types of vehicle ownership, specifically car, motorcycle and bicycle, in Osaka, Japan, and Kuala Lumpur, Malaysia, applying simultaneous vehicle ownership models. The findings indicate that motorcycles are deemed as substitutes for cars in Kuala Lumpur whereas bicycles are deemed as substitutes for cars in Osaka. The high population in Osaka leads to bicycles as substitutes for cars, while the high car travel times lead to motorcycles as substitutes for cars in Kuala Lumpur. Similar results supporting the substitution relationship between cars and motorcycle in Kuala Lumpur, Malaysia, and Bangkok, Thailand, but a complementary relationship in Nagoya, Japan, were stated by Sanko et al., (2014), who explored car and motorcycle ownership employing a bivariate ordered probit model in these three locations. Intriguingly, while the income variable was not incorporated in the model, other socio-demographic variables, including household size, gender, and age, were indicated to have a positive and significant relationship with motorcycle ownership.

In studies conducted in Taiwanese cities, Hsu et al., (2007) and Chiou et al., (2009) discovered a substitution relationship between cars and motorcycle. Hsu et al., (2007) further recognised that the provision of public transportation inhibits motorcycle ownership in cities with a better public transportation system. Senbil et al., (2007) investigated the interdependent relationship between car and motorcycle ownership in Jabotabek, Indonesia, Manila, Philippines, and Kuala Lumpur, Malaysia. The outcome of the research, which utilized a bivariate ordered probit model, suggested that there is no relationship between the former and the latter, with the exception of a substitution relationship for Kuala Lumpur. They further explain that income has a larger impact on car ownership than it does on motorcycle ownership. In a distinct geographical region, Anastasopoulos et al., (2012) and Gómez-Gélvez and Obando (2014) discovered a negative relationship between car and motorcycle ownership in Athens, Greece, and Bogota, Colombia, respectively. A small number of studies are identified in the perspective of the developed world. Majority of the studies on the car and motorcycle ownership interdependency mainly stem from the developing world, mainly in the South Asian and Southeast Asian regions, with interest concentrated on disaggregate based modelling. This is for the reason that motorcycle ownership is deemed as one of the key modes of transport in the region, and there is low motorcycle ownership in developed countries in comparison with the developing countries. This is because public transport is identified as the substitute for cars in developed countries as a result of improved public transport infrastructure. 
Henceforth, very limited evidences are observed in the literature examining this subject matter. Interestingly, few studies were found on the aggregate level compared to the disaggregate level. Given this condition, there is a necessity to better comprehend the interdependency between these two modes to investigate the relationship based on the aggregate study.

\section{METHODOLOGY}

This study aims to investigate the determinants of car ownership and the interdependency between car and motorcycle ownership in the Sarawak, Malaysia. For this purpose, a model is constructed in which the dependent variable consists of car ownership (CAR) while the dependent variables consist of real gross domestic product (RGDP), fuel price (FP), population density (PD) and motorcycle ownership (MOTOR). The functional model (and expected signs) employed to investigate the relationship can be expressed as follows:

$$
\begin{aligned}
& \mathrm{CAR}=\mathrm{f}(\text { MOTOR, RGDP, FP, PD) } \\
& (-) \quad(+) \quad(-) \quad(-)
\end{aligned}
$$

\begin{tabular}{|c|c|c|c|}
\hline Variable & Description & Source & References \\
\hline RGDP & $\begin{array}{l}\text { Real Gross Domestic } \\
\text { Product per capita }\end{array}$ & DOSM (2019) & $\begin{array}{l}\text { (Pongthanaisawan \& Sorapipatana, 2010; } \\
\text { Reza \& Spiro, 1979; Romilly et al., 1998; } \\
\text { Samad Nawi et al., 2013; Islam et al., } \\
2016 \text { ) }\end{array}$ \\
\hline CAR & $\begin{array}{l}\text { Total number of cars per } \\
1000 \text { inhabitants }\end{array}$ & DOSM (2019) & $\begin{array}{l}\text { (Pongthanaisawan \& Sorapipatana, 2010; } \\
\text { Tuan, 2011) }\end{array}$ \\
\hline MOTOR & $\begin{array}{l}\text { Total number of } \\
\text { motorcycle per } 1000 \\
\text { inhabitants }\end{array}$ & DOSM (2019) & $\begin{array}{l}\text { (Pongthanaisawan \& Sorapipatana, 2010; } \\
\text { Tuan, 2011) }\end{array}$ \\
\hline FP & $\begin{array}{l}\text { RON97 price }(2010 \\
\text { constant price) in USD }\end{array}$ & MDTCC (2019) & $\begin{array}{l}\text { (Reza \& Spiro, 1979; Graham \& Glaister, } \\
\text { 2002; Goodwin, Dargay, \& Hanly, 2004) }\end{array}$ \\
\hline PD & $\begin{array}{l}\text { Total population per } \\
\text { land area (population } \\
\text { per } \mathrm{km}^{2} \text { ) }\end{array}$ & DOSM (2019) & (Sanghi, 1976) \\
\hline
\end{tabular}

Table 2: List of Variables

The variables (Equation 1) were selected based on past literatures on private vehicle ownership that employed aggregate time series model (Sanghi, 1976; Reza \& Spiro, 1979; Romilly et al., 1998; Pongthanaisawan \& Sorapipatana, 2010; Tuan, 2011; Samad Nawi et al., 2013; Islam et al., 2016). Table 2 presents a description of the data. Income changes are expected to positively affect vehicle demand. Consequently, income implies the economic situation of citizens, in which the wealth accumulation would make people more affluent and, as a result, generate greater demand for cars and motorcycles. Moreover, the travelling cost is an important element in vehicle demand as well as fuel price, which is used as the proxy for the transportation cost. Thus, this study presumes that a rise in the price of fuel could lead to lowering the frequency of travelling, which generates negative elasticity for road-based vehicle demand. While some of the macroeconomic indicators are based on Malaysian based studies by Samad Nawi et al., (2013) and Islam et al., 
(2016), a variable was obtained to represent the effect of built-environment specifically population density. Studies by Newman \& Kenworthy (1989) and Hess \& Ong (2002) suggest that higher density is associated with lower vehicle ownership due to various factors such as stronger travel options and shorter distance to travel. Owing to the limited data availability, the data are selected from 1980 to 2018 (DOSM, 2019; MDTCC, 2019).

The choice of the time series model firstly relies on the stationarity of the models. Time series variables that are stationary at level may use the ordinary least squares (OLS) regression. Time series variables which are non-stationary at level but are stationary at first difference may continue with the Johansen and Juselius cointegration test (Johansen \& Juselius, 1990). Time series variables that are cointegrated may advance with error correction models, while non-cointegrated variables may continue with the vector autoregressive (VAR) model. Mixed variables (Stationary at I (0), I (1)) may proceed with the autoregressive distributive lag (ARDL) model (Shrestha \& Bhatta, 2018). Thus, it is presumed that the vector error correction model (VECM) is appropriate to analyse the aggregate time series modelling in this study. It is known that the merit of VECM involves the capability to have a reasonable explanation of long-term and short-term equations. Furthermore, Maysami and Koh (2000) stressed that the model could be utilized to investigate the dynamic co-movement among the variables as well as the adjustments process to attain a longterm equilibrium. For this study, a three-step testing procedure is applied. First, the Augmented Dickey Fuller (ADF) unit root test (Dickey \& Fuller, 1979) and Phillip-Perron test (PP) is used to test the presence of unit root. Second, Johansen-Juselius cointegration test is applied to detect the presence of long-run relationship in the model. Third, following the long-run relationship detection in the model, the study progresses with the Vector Error Correction Model (VECM) to estimate the long-run relationship and the short-run causality. A model of the Vector Autoregressive (VAR) is defined as the dynamic evolution of several variables guided by their shared history (Verbeek, 2008). The Vector Error Correction Model (VECM) is a VAR extension that indicates the existence of cointegration, in particular the long-run relationship between the variables. However, the VAR model does not address such long-term relationships. A lagged term for error correction (ECT) can then be found in the VECM and ECT, which is a term for error correction originating from the long-term cointegrating relationship (Pojanavatee, 2014). In addition to these, the Granger causality test is performed to determine the causality between variables. In the case of a cointegration for car model the following equation describes the VECM.

$$
\begin{aligned}
\Delta L N C A R_{t}= & \alpha_{0} \sum_{i=1}^{m} \beta_{1, i} \Delta L N C A R_{t-i}+\sum_{i=1}^{m} \beta_{2, i} \Delta L N M O T O R_{t-i}+\sum_{i=1}^{m} \beta_{3, i} \Delta L N R G D P_{t-i}+ \\
& \sum_{i=1}^{m} \beta_{4, i} \Delta L N F P_{t-i}+\sum_{i=1}^{m} \beta_{5, i} \Delta L N P D_{t-i}+\theta_{1} E C T_{t-1}+\varepsilon_{1 t}
\end{aligned}
$$

Where $\Delta$ indicates the lag operator; $\alpha_{0}, \beta$ s are the estimated coefficients; $m$ is the optimal lag length, $\varepsilon_{\mathrm{t}}$ is the residual; $\theta$ measures the response of LNCAR to departure from equilibrium. ECT measures the speed of adjustment if there is a deviation in long-run equilibrium; it will be corrected by shortrun adjustments. This will be shown by ECT that is negative and statistically significant. In testing whether LNMOTOR does not Granger cause LNCAR; $\mathrm{H}_{0}: \beta_{2}, \mathrm{i}=0$ for all $\mathrm{i}$. The rejection of $\mathrm{H}_{0}$ shows that LNMOTOR causes LNCAR. 


\section{RESULTS AND DISCUSSION}

The empirical results in this study include the results of unit root tests, Johansen and Juselius test and VECM model. According to the ADF test, the null hypothesis of no unit root is rejected at level for all variables for both the ADF and PP test. This indicates that the data have non-stationary, which means that the mean, variance and autocorrelation are not constant over time. Following the non-stationarity at level, the unit root tests are then tested at the first difference (for example, $\left.\mathrm{RGDP}_{\mathrm{t}}-\mathrm{RGDP}_{\mathrm{t}-1}\right)$ for all variables. In contrast, all the variables were stationary after first differencing, which implies that they were integrated at I (1) and are non-spurious. Correspondingly, the results revealed that the null hypothesis containing the unit root had failed to be rejected for all variables at a level based on the PP test. At the first difference, it was found that the null hypothesis was rejected at the first difference. This showed that the variables were integrated at order 1 . The findings implying the same order of integration permit for the Johansen and Juselius' cointegration test to be taken.

Table 3: Unit Root Test

\begin{tabular}{lcccc}
\hline \hline \multirow{2}{*}{ Variables } & \multicolumn{2}{c}{ Augmented Dickey-Fuller } & \multicolumn{2}{c}{ Phillip-Peron } \\
\cline { 2 - 5 } & Level & First Difference & Level & First Difference \\
\hline $\ln$ CAR & -3.334 & $-6.514^{* *}$ & -3.137 & $-9.930^{* *}$ \\
$\operatorname{lnMOTOR}$ & -1.648 & $-5.312^{* *}$ & -1.837 & $-5.311^{* *}$ \\
$\operatorname{lnRGDP}$ & -1.643 & $-4.767^{* *}$ & -1.695 & $-4.787^{* *}$ \\
$\operatorname{lnFP}$ & -1.769 & $-4.754^{* *}$ & -1.834 & $-4.820^{* *}$ \\
$\operatorname{lnPD}$ & -1.877 & $-5.923^{* *}$ & -1.897 & $-5.923^{* *}$ \\
\hline
\end{tabular}

Notes: ** represent $5 \%$ level of significance.

The cointegration test was applied to decide the type of model to be used for the analysis. In Particular, the Johansen and Juselius test was performed to test for the presence of a cointegrating relationship for the variables to ascertain whether there is a long-run relationship or otherwise. The existence of cointegration indicates that there is a long-run relationship for the model, which permits the VECM model to be conducted. The cointegration test results for the car ownership model are shown in Table 4. Based on the cointegration test results, both the null hypothesis of no cointegration for trace statistics and the Max-Eigen are rejected. This confirms that the model possessed a cointegrating vector, which denotes that the variables do not drift away from each other and share a common long-run stochastic relationship. Generally, the result also demonstrates that the assumption of non-causality among the variables is to be ruled out and that a long-run relationship exist in both models. Consequently, this enables for the VECM to be performed to identify the long-run and short-run relationships for the models in Table 5 and Table 6. The VECM can be analysed due to the non-causality being rejected based on the Johansen Juselius cointegration test in Table 4 . The outcome for the VECM for the car ownership model is presented in Table 5 and Table 6. 
Table 4: Johansen and Juselius Cointegration Test Results

\begin{tabular}{lccccc}
\hline \hline H0: & H1: & $\begin{array}{c}\text { Trace } \\
\text { Statistics }\end{array}$ & Critical Value & $\begin{array}{c}\text { Max-Eigen } \\
\text { Statistic }\end{array}$ & Critical Value \\
\hline $\mathrm{r}=0$ & $\mathrm{r}=1$ & $107.350^{* *}$ & 95.754 & $40.913^{* *}$ & 40.078 \\
$\mathrm{r} \leq 1$ & $\mathrm{r}=2$ & 66.437 & 69.819 & 25.985 & 33.877 \\
$\mathrm{r} \leq 2$ & $\mathrm{r}=3$ & 40.457 & 47.856 & 19.029 & 27.584 \\
$\mathrm{r} \leq 3$ & $\mathrm{r}=4$ & 21.423 & 29.797 & 11.778 & 21.132 \\
$\mathrm{r} \leq 4$ & $\mathrm{r}=5$ & 9.644 & 15.495 & 9.4233 & 14.265 \\
\hline \hline
\end{tabular}

Notes: $(* *)$ denotes rejection of the hypothesis at the 5\%. The letter "r" represents the number of co-integrating equations. The critical values are based on Osterwald-Lenum (1992).

Generally, the result also demonstrates that the assumption of non-causality among the variables is to be ruled out and that a long-run relationship exist in both models. Consequently, this enables for the VECM to be performed to identify the long-run and short-run relationships for the models in Table 5 and Table 6. The VECM can be analysed due to the non-causality being rejected based on the Johansen Juselius cointegration test in Table 4. The outcome for the VECM for the car ownership model is presented in Table 5 and Table 6 . Table 5 shows the long-run relationship between the parameters of interest. For the normalized cointegrating vectors, the estimated sign for LMOTOR, LRGDP, LFP and LPD are consistent with the expected sign. The output shows that LMOTOR, LRGDP, LFP and PD are statistically significant at 5 per cent significant level. It is shown that the long-run car ownership elasticities in regard to RGDP is 2.028 which is supported by studies in past literatures (Romilly et al., 1998; Samad Nawi et al., 2013; Islam et al., 2016;). Negative elasticities were discovered for fuel price (-1.688). This is supported by (Ubaidillah, 2019). The results also show that higher population density leads towards lower ownership (-0.410) which is supported by past studies by Hess \& Ong (2002). The outcomes also indicate a long-run substitution relationship between car and motorcycle ownership (-2.208) (Pongthanaisawan \& Sorapipatana, 2010; Tuan, 2011).

Table 5: Normalised cointegrating vectors

\begin{tabular}{lccccc}
\hline \hline Variables & LCAR & LMOTOR & LRGDP & LFP & LPD \\
\hline Coefficient & 1.000 & -2.208 & 2.028 & -1.688 & -0.410 \\
(t-statistics) & & $(-4.768)^{* *}$ & $(5.595)^{* *}$ & $(-5.024)^{* *}$ & $(-4.346)^{* *}$ \\
\hline \hline
\end{tabular}

Notes: ** represent $5 \%$ level of significance.

Based on Table 6, the value of the error correction term (ECT) was shown to have an expected coefficient that is negative with the significant $t$-statistics value that matches the outcome $(-0.578)$. Due to short-run disturbances, it requires 58 per cent per year for the car ownership model to adjust to the long-run equilibrium. Such outcomes reveal the adjustment made by car ownership to achieve long-run equilibrium in the case of any shocks in the market (for example, the increase in fuel price). The VECM short-run causal relationship outcomes are displayed in Figure 3. The findings found that there is a unidirectional short-run causal relationship from RGDP and FP to both car and motorcycle ownership. This is aligned with the long-run relationship from RGDP and FP to car ownership. 
Table 6: Results of VECM Based Granger Causality

\section{Independent variables}

\begin{tabular}{|c|c|c|c|c|c|c|}
\hline \multirow{2}{*}{$\begin{array}{c}\text { Dependent } \\
\text { variables }\end{array}$} & \multicolumn{5}{|c|}{$\chi^{2}$ statistics of lagged $1^{\text {st }}$ differenced term [p-value] } & \multirow{2}{*}{$\begin{array}{c}\text { Ect }_{t-1} \\
\text { coefficient } \\
\text { (t-stat) }\end{array}$} \\
\hline & $\Delta \operatorname{lnCAR}$ & $\Delta \operatorname{lnMOTOR}$ & $\Delta \operatorname{lnRGDP}$ & $\Delta \operatorname{lnFP}$ & $\Delta \ln \mathrm{PD}$ & \\
\hline \multirow[t]{2}{*}{$\Delta \operatorname{lnCAR}$} & - & 0.158 & 0.012 & 0.024 & 0.721 & $-0.578 * *$ \\
\hline & & [0.691] & [0.913] & [0.877] & [0.396] & $(-3.691)$ \\
\hline \multirow[t]{2}{*}{$\triangle \operatorname{lnMOTOR}$} & 0.000 & - & 0.448 & 0.131 & 0.264 & 0.032 \\
\hline & [0.985] & & [0.503] & {$[0.717]$} & {$[0.608]$} & $(0.525)$ \\
\hline \multirow[t]{2}{*}{$\Delta \operatorname{lnRGDP}$} & 5.561 & 3.587 & - & 0.680 & 0.523 & 0.084 \\
\hline & {$[0.0184]^{* *}$} & {$[0.058]^{*}$} & & [0.410] & [0.469] & $(0.889)$ \\
\hline \multirow[t]{2}{*}{$\Delta \ln F P$} & 6.975 & 5.579 & 0.009 & - & 0.052 & -0.024 \\
\hline & {$[0.008]^{* * *}$} & {$[0.018]^{* *}$} & [ 0.923$]$ & & [0.819] & $(-0.164)$ \\
\hline \multirow[t]{2}{*}{$\Delta \ln P D$} & 1.350 & 0.740 & 0.103 & 0.523 & - & -0.236 \\
\hline & {$[0.245]$} & [0.390] & {$[0.748]$} & [0.470] & & $(-1.520)$ \\
\hline
\end{tabular}

Note: $* * *, * *, *$ denotes significant at $1 \%, 5 \%, 10 \%$ significant level, respectively. The figure in parenthesis (...) denote as t-statistics and the figure in the squared brackets $[\ldots]$ represent as p-value.

Figure 3: Short-run Causal Relationship

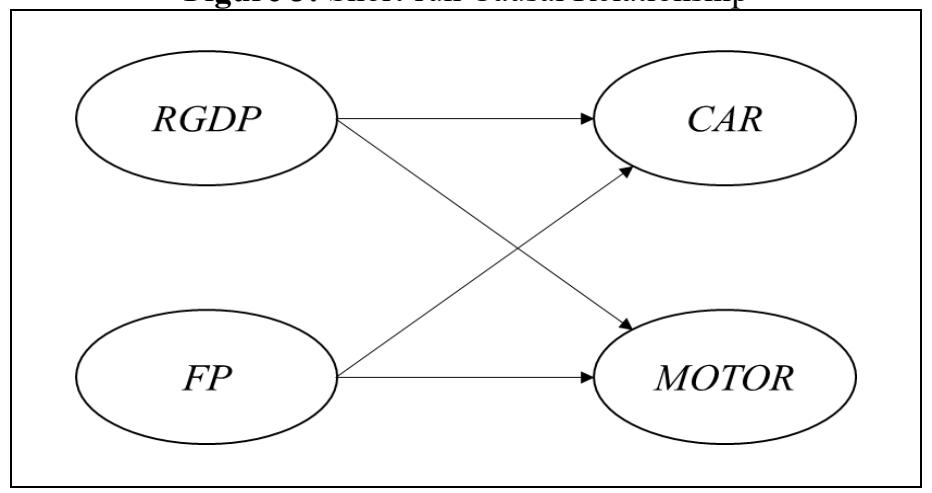

This study is able to identify the determinants of car ownership at the aggregate level for a state in a developing country with a high level of car and motorcycle ownership. First, the findings revealed that there is a substitution relationship between cars and motorcycles in the long-run. Based on the outcome, it is very likely that there will be a shift from motorcycle to car ownership as the number of car ownership increases in the long run. The outcome is aligned with the outcomes from Tuan (2011). Nevertheless, the relationship presented in the results are more elastic $(-2.208)$ than that shown by Tuan (2011) [-0.24 for Malaysia; -0.15 for Japan]. It is apparent that there is a long-run dependence between car and motorcycle ownership in Malaysia, as exhibited at the country and at the state level (Sarawak). The stronger relationship at the state aggregate level in comparison with the country aggregate level suggests that there might be lower car and motorcycle dependence in other states in Malaysia, which might be caused by other transport alternatives for example public bus and train. In Sarawak perspective, in particular Kuching city, cars have been recognized as the 
most common transport mode throughout age, income and occupation classes (Lim, Jacob, Issac, \& Lim, 2007).

This is as a result of problems in public bus services, for instance reliability, trustworthiness, readiness of bus schedules, bus route occurrence and the cleanliness. The findings also suggested that there is a stronger reliance between car and motorcycle ownership in Sarawak compared to a developed country. Japan has been known for its well-known shinkansen (bullet train), trains, subway and buses, which deliver clean, dependable, punctual and convenient public transport services for the consumers. This can be viewed from the modal shares of passenger transport in Tokyo, Japan, in 2003 (Fujimoto, 2008). Although there is a sizeable share for passenger cars (33 per cent), the remaining which refer to other modes, such as Japan railways (25 per cent), private railways ( 23 per cent), subway (13 per cent) and buses ( 6 per cent). This result could also be credited to various transport infrastructure and services alternatives (apart from public buses and train), as a result of improved walking and cycling amenities offered in a developed country as against a developing country. The outcome of substitution relationship from motorcycle to car ownership also indicates that the policymakers have to deal with higher level of dependency primarily on car ownership in Malaysia which leads to continuous rise of fuel consumption and carbon emissions in the long-run.

\section{CONCLUSION}

With the exception of the above-mentioned discussions, the result of this study sheds light on the interdependency between car and motorcycle ownership at the aggregate level in the long run. Firstly, there is a negative and elastic relationship motorcycle ownership towards car ownership. This suggests that in the long run people are likely to move from owning motorcycles to cars. Secondly, there is a same substitution relationship between car and motorcycle ownership in the country at the aggregate level (Malaysia, as studied by Tuan, 2011) and at the state aggregate level (Sarawak). Nevertheless, the relationship is stronger at the state aggregate level. Motorcycles are deemed as a vital transport mode in developing countries for numerous causes, comprising low purchase cost, low maintenance cost and easy manoeuvring on the road. In contrary, there are significantly smaller number of motorcycles in developed countries as compared with developing countries as motorcycles are commonly considered for recreational purpose. Further to this, the third outcome indicates that there is a similar substitution relationship between car and motorcycle ownership with that of a developed country, specifically Japan (Tuan, 2011). Nonetheless, the relationship is found to be inelastic in the case of the developed country because of the existence of other viable modes of transport. Although it is true that socio-economic variables significantly affect people to have more cars or motorcycles, there are other aspects which are yet to be investigated that cannot be supported using aggregate data. These may include the incorporation of individual preferences, including the psychological elements as the car and motorcycle ownership determining factor, particularly in urban areas. Hence, the role of the disaggregate study is suggested to obtain further insights at the micro level.

Several policy recommendations are suggested in order to achieve long-term sustainable transport considering the high level of car-dependency in the Sarawak, Malaysia. First, it is imperative to expand the fleet of hybrid electric vehicle (HEV) and electric vehicle (EV) in the country. That can also be complemented by enhancing the battery vehicle range as well as increasing the number of 
EV charging facilities. In addition to that, policy-makers can provide ridesharing services (and customers) with incentives by using EV cars. To date, there are very few EV charging facilities in the country. Second, to improve the alternative transport options which are more sustainable than private motorisation such as public buses, walking and cycling facilities. For the case of Putrajaya, Malaysia, a city in a developing country, the application of walkability is still low (Hashim, Hashim, $\&$ Shuib, 2017). As Malaysia is a hot climate country, the inability to offer shades for pedestrians and cyclists dissuades people from walking and cycling. Hashim et al., (2017, p. 104) further explained the main causes for limited bicycle usage, includes a "lack of appropriate infrastructure, lack of promotion, not enough cycle lane, cycle lane not well designed, and lack of maintenance". Hence, future improvements in these facilities should address these deficiencies.

\section{ACKNOWLEDGEMENT}

The author would like to thank Ministry of Education, Malaysia and Universiti Malaysia Sarawak for funding this research. This article is part of the thesis from Ubaidillah (2019).

\section{REFERENCES}

Anastasopoulos, P., Karlaftis, M., Haddock, J., \& Mannering, F. (2012). Household Automobile and Motorcycle Ownership Analyzed with Random Parameters Bivariate Ordered Probit Model. Transportation Research Record: Journal of the Transportation Research Board, 2279, 12-20. doi: https://doi.org/10.3141/2279-02

Barter, P. (1999). An International Comparative Perspective on Urban Transport and Urban Form in Pacific Asia: The Challenge of Rapid Motorisation in Dense Cities. Murdoch University. Retrieved from http://researchrepository.murdoch.edu.au/3332/

Census and Economics Information Centre (CEIC). (2019). Malaysia Motor Vehicles Registration. Retrieved from https://www.ceicdata.com/en/malaysia/motor-vehicles-registration

Chiou, Y. C., Wen, C. H., Tsai, S. H., \& Wang, W. Y. (2009). Integrated modeling of car/motorcycle ownership, type and usage for estimating energy consumption and emissions. Transportation Research Part A: Policy and Practice, 43(7), 665-684. doi: https://doi.org/10.1016/j.tra.2009.06.002

Davis, S., \& Boundy, R. (2019). Transportation Energy Data Book. Annual Review of Energy and the Environment $\left(37^{\text {th }}\right.$ ed.). US: Department of Energy. Retrieved from https://doi.org/10.1146/annurev.energy.14.1.375

Department of Statistics Malaysia (DOSM). (2016). Household Income and Basic Amenities Survey. Putrajaya.

Department of Statistics Malaysia (DOSM). (2019). Malaysia Yearly Book of Statistics. Putrajaya.

Dickey, D. A., \& Fuller, W. A. (1979). Distribution of the estimators for autoregressive time series with a unit root. Journal of The American Statistical Association, 74(366), 427-431. doi: https://doi.org/10.2307/2286348

Fujimoto, H. (2008). The Modal Shift to Environmentally Sustainable Transport: Prospects of Urban Transport Systems: LRT, BRT and Buses. Science \& Technology Trends Quarterly Review. Tokyo. doi: https://doi.org/10.1017/CBO9781107415324.004

Gómez-Gélvez, J. A., \& Obando, C. (2014). Joint Disaggregate Modeling of Car and Motorcycle Ownership. Transportation Research Record: Journal of the Transportation Research 
Board, 2451(1), 149-156. doi: https://doi.org/10.3141/2451-17

Goodwin, P., Dargay, J., \& Hanly, M. (2004). Elasticities of road traffic and fuel consumption with respect to price and income: A review. Transport Reviews, 24(3), 275-292. doi: https://doi.org/10.1080/0144164042000181725

Graham, D. J., \& Glaister, S. (2002). The demand for automobile fuel: A survey of elasticities. Journal of Transport Economics and Policy, 36(1), 1-26.

Hashim, S. F., Hashim, H., \& Shuib, K. B. (2017). Residents' perspective on cycling as an option for transportation in Putrajaya. Planning Malaysia, 6, 97-108. doi: https://doi.org/10.21837/pmjournal.v16.i6.271

Herwangi, Y. (2018). Motorcycle dependency in low-income people : modeling spatial and socioeconomic factors in urbanized area of yogyakarta. Jurnal Plano Madani, 7(2), 196-208.

Hess, D. B., \& Ong, P. M. (2002). Traditional neighborhoods and automobile ownership. Transportation Research Record, (1805), 35-44. doi: https://doi.org/10.3141/1805-05

Hsu, T. P., Tsai, C. C., \& Lin, Y. J. (2007). Comparative Analysis of Household Car and Motorcycle Ownership Characteristics. Journal of the Eastern Asia Society for Transportation Studies, 7, 105-115.

Hsu, T. P., Mohd. Sadullah, A. F., \& Nguyen, X. D. (2003). A comparative study on motorcycle traffic development of Taiwan, Malaysia and Vietnam. The Eastern Asia Society for Transportation Studies (EASTS). Retrieved from http://citeseerx.ist.psu.edu/viewdoc/ download?doi=10.1.1.460.2229\&rep=rep1\&type=pdf

Islam, R., Ghani, A. B. A., Kusuma, B., \& Hong, E. T. Y. (2016). An analysis of factors that affecting the number of car sales in Malaysia. International Review of Management and Marketing, 6(4), 872-882.

Johansen, S., \& Juselius, K. (1990). Maximum likelihood estimation and inference on cointegration- with applications to the demand for money. Oxford Bulletin of Economics and Statistics, 52(2), 169-210. doi: https://doi.org/10.1111/j.14680084.1990. mp52002003.x

Lim, B., Jacob, S. M., Issac, B., \& Lim, E. (2007). Efficient Transport And Economic Development: A Transport Survey Analysis. In International Economic Conference on Trade and Industry (IECTI) (pp. 1-15). Penang. Retrieved from http://repo.uum.edu.my/2397/

Maysami, R. C., \& Koh, T. S. (2000). A vector error correction model of the Singapore stock market. International Review of Economics and Finance, 9(1), 79-96. doi: https://doi.org/10.1016/S1059-0560(99)00042-8

Ministry of Domestic Trade Co-operatives and Consumerism (MDTCC). (2019). Malaysian Fuel Price. Putra Jaya.

Newman, P. W. G., \& Kenworthy, J. R. (1989). Gasoline consumption and cities: A comparison of U.S. cities with a global survey. Journal of the American Planning Association, 55(1), 24-37. doi: https://doi.org/10.1080/01944368908975398

Organisation Internationale des Constructeurs d'Automobiles (OICA). (2018). World Motor Vehicle. International Organization of Motor Vehicle Manufacturers. Retrieved from http://www.oica.net/

Pojanavatee, S. (2014). Cointegration and causality analysis of dynamic linkage between stock market and equity mutual funds in Australia. Cogent Economics and Finance, 2(1), 1-17. doi: https://doi.org/10.1080/23322039.2014.918855

Pongthanaisawan, J., \& Sorapipatana, C. (2010). Relationship between level of economic development and motorcycle and car ownerships and their impacts on fuel consumption and 
greenhouse gas emission in Thailand. Renewable and Sustainable Energy Reviews, 14(9), 2966-2975. doi: https://doi.org/10.1016/j.rser.2010.07.034

Reza, A., \& Spiro, M. (1979). The demand for passenger car transport services and for gasoline. Journal of Transport Economics and Policy, 13(3), 304-319. doi: http://www.jstor.org/stable/10.2307/20052550

Romilly, P., Song, H., \& Liu, X. (1998). Modelling And Forecasting Car Ownership In Britain. A Cointegration And General To Specific Approach. Journal of Transport Economics and Policy, 32(2), 165-185.

Samad Nawi, A., Bashir Ahmad, S. A., Mahmood, W. M. W., Sekharan Nair, G. K., Siti Nurathirah, A., \& Abdul Hamid, B. (2013). Determinants of passenger car sales in Malaysia. World Applied Sciences Journal, 23, 67-73. doi: https://doi.org/10.5829/idosi.wasj.2013.23.eem cge. 22013

Sandu, M. C. (2015). A Time Series Analysis Using R for Understanding Car Sales On The Romanian Market. Revista RomâNă de Statistică, 63(3), 130-140.

Sanghi, A. K. (1976). The relationship between population density, automobile ownership and automobile use: Its role in transportation planning. Ann Reg Sci, 10, 118-127. doi: https://doi.org/10.1007/BF01291240

Sanko, N., Dissayanake, D., Kurauchi, S., Maesoba, H., Yamamoto, T., \& Morikawa, T. (2014). Household car and motorcycle ownership in Bangkok and Kuala Lumpur in comparison with Nagoya. Transportmetrica, 10(3), 187-213.

Senbil, M., Zhang, J., \& Fujiwara, A. (2007). Motorization in Asia. IATSS Research, 31(1), 46-58. doi: https://doi.org/10.1016/S0386-1112(14)60183-7

Shrestha, M. B., \& Bhatta, G. R. (2018). Selecting appropriate methodological framework for time series data analysis. The Journal of Finance and Data Science, 4(2), 71-89. doi: https://doi.org/10.1016/j.jfds.2017.11.001

Tuan, V. A. (2011). Dynamic Interactions between Private Passenger Car and Motorcycle Ownership in Asia: A Cross-country Analysis. Journal of the Eastern Asia Society for Transportation Studies, 9, 541-556.

Ubaidillah, N. Z. (2019). Determinants of Car and Motorcycle Ownership and Use in Sarawak. University of Leeds. Retrieved from http://etheses.whiterose.ac.uk/id/eprint/26409

United Nation. (2015). Analysis of the Transport Relevance of Each of the 17 SDGs. Retrieved from https://sustainabledevelopment.un.org/content/documents/8656Analysis of transport relevance of SDGs.pdf

United Nation. (2018). Accelerating SDG7 Achievement Policy Briefs in Support of the First SDG7 Review at the UN High-Level Political Forum 2018. Retrieved from https://sustainabledevelopment.un.org/content/documents/17501PB16.pdf

Verbeek, M. (2008). A Guide to Modern Econometrics ( $3^{\text {rd }}$ Ed). Chichester, England: John Wiley $\&$ Sons.

Yamamoto, T. (2009). Comparative analysis of household car, motorcycle and bicycle ownership between Osaka metropolitan area, Japan and Kuala Lumpur, Malaysia. Transportation, 36(3), 351-366. doi: https://doi.org/10.1007/s11116-009-9196-x 